\title{
12. Outsiders or Insiders? Strategic Choices for Australian Indigenous Leadership
}

\section{Will Sanders}

\section{The outsider-insider conundrum}

In the last couple of years, Cape York Aboriginal leader, Noel Pearson, has taken to writing regular columns in The Weekend Australian newspaper. On 7-8 July 2007, he wrote a column in which he reflected on the reactions of Indigenous leaders to the then recently announced Commonwealth 'intervention' in Northern Territory Aboriginal communities, following the Northern Territory Government's Little Children are Sacred report (BIPACSA 2007). Pearson was critical of Indigenous leaders, such as the Northern Territory Government minister Marion Scrymgour and the former Chief Executive Officer of ATSIC and now head of National Indigenous Television (NITV), Pat Turner, who were 'nay-saying' the intervention. He suggested that there was a 'psychological incapacity' among many Indigenous leaders 'to step up to politics in mainstream Australia' and that this was 'one of the reasons' why Indigenous people 'continue to lose in this country'. Indigenous leaders, he argued, 'have to deal with the Government and the politics of the day and devote our maximum energies and talents towards making good of things that otherwise seem bad' (Pearson 2007a).

Pearson seems to be arguing that more Indigenous leaders need to become 'insiders' of Australian political processes who engage strategically with whatever political circumstances emerge and whoever is in government. Conversely he seems to suggest that, psychologically, many Indigenous leaders are locked into an 'outsider' position of inflexible stand-taking, on the basis of history, identity or philosophical commitment. The terms 'insider' and 'outsider', as descriptors of Australian Indigenous leadership styles, are my own rather than Pearson's. But I do think they are a convenient way to capture Pearson's argument. My aim in this chapter is not specifically to agree or disagree with Pearson's argument and judgment about the psychology of most Indigenous leaders, but rather just to think some more about the ins and outs of Australian Indigenous leadership: how, when and why Indigenous leaders use insider and outsides stances. My own, more analytic, argument is that these leadership styles are complementary, that they entail and feed off each other systemically in public life, rather than existing as clear alternatives between which individual Indigenous leaders can always be clearly allocated. I will begin, however, by making a few comments about the apparent relative numbers of Indigenous leaders in three constituent 
and overlapping spheres of 'public leadership' the political, administrative and civic.

\section{Forms of indigenous leadership: political, administrative and civic}

At first glance there is a dearth of Indigenous political leaders in Australia. There have only ever been two Indigenous Commonwealth parliamentarians Queensland Liberal Senator Neville Bonner from 1971 to 1983 and New South Wales Australian Democrats Senator Aden Ridgeway from 1999 to 2005. At the state and territory level, there have historically also been very few Indigenous parliamentarians, although currently there is something of a bumper crop two in Western Australia, one each in Tasmania and New South Wales and six in the Northern Territory, all representing the Australian Labor Party. Indeed in 2007, very unusually, there were three Indigenous ministers in Australian state and territory governments, Linda Burney in New South Wales and Marion Scrymgour and Elliot McAdam in the Northern Territory. Prior to these three however, there have, to my knowledge, only ever been two other Indigenous ministers in state and territory governments - Ernie Bridge in Western Australia in the 1990s and John Ah Kit in the Northern Territory in the early 2000s.

There is, however, another way to count Indigenous political leaders which, by definition, leads to greater numbers. This is to include members of the elected national Indigenous representatives bodies which existed from 1973 to 2005, the National Aboriginal Consultative Committee from 1973 to 1977, the National Aboriginal Conference from 1977 to 1985 and the Aboriginal and Torres Strait Islander Commission (ATSIC) from 1990 to 2005. ATSIC had some hundreds of elected regional councillors who in turn elected seventeen national Commissioners, and from 1999 these Commissioners elected their own Chairperson. While the first elected ATSIC Chairperson, Geoff Clark from Victoria, enjoyed some national public prominence, the position was abolished before it became institutionalised. Interestingly, one of the national ATSIC Commissioners from 1999 to 2004, Alison Anderson from Central Australia, has gone on to become a Northern Territory parliamentarian. But I am unaware of any other ATSIC Commissioners, or regional council members, who have made the transition from elected national Indigenous representative body to parliamentarian.

There is also a dearth, at first glance, of Indigenous administrative leaders. Perhaps the most prominent of recent years has been Pat Turner, the CEO of ATSIC from 1994 to 1997, who later went on to become a deputy CEO of Centrelink before retiring from the public service and becoming the head of National Indigenous Television. A little earlier, Lois (now Lowitja) O'Donoghue enjoyed some public prominence as ATSIC's appointed Chairperson from 1990 to late 1996, followed by Gatjil Djerrkura to late 1999. Another administrative position of public prominence for Indigenous people in recent years has been 
that of Aboriginal and Torres Strait Islander Social Justice Commissioner within the Human Rights and Equal Opportunity Commission (HREOC), filled by Mick Dodson from 1993 to 1998, Bill Jonas from 1999 to 2004 and Tom Calma since 2004. As five-year statutory appointees, these HREOC Commissioners have considerable autonomy to reflect critically on what other parts of government are doing. However having done so, their position seems to be more that of passing Indigenous advocate than career public servant. Both Dodson and Jonas moved outside the public service at the end of their five-year statutory appointment. And the same pattern can be observed with the two Indigenous Chairpersons of the Commonwealth-appointed Council for Aboriginal Reconciliation, Pat Dodson from 1991 to 1997 and Evelyn Scott from 1998 to 2000.

In an earlier generation, back in the 1970s and 1980s, the most prominent Indigenous career public servant was Charles Perkins, who joined the new Commonwealth Office of Aboriginal Affairs in the late 1960s and rose through the ranks of the Department of Aboriginal Affairs established in 1972 to become its Secretary from 1984 to 1988, as well as being the inaugural chairperson of its statutory off-shoot the Aboriginal Development Commission from 1980 to 1984. Perkins commanded far greater public attention than most Australian administrative leaders, even before he was a statutory officer. This could possibly be attributed to him having worked in leadership roles in Indigenous community organisations before becoming a career public servant, but also to his strong sense of being an advocate for Indigenous interests within the public service. Indeed, Perkins' public service career came to a slightly premature end in 1988 when his advocacy of the interests of an Indigenous community sector organisation for Commonwealth funding became unacceptable to his minister, Gerry Hand, who saw it as a conflict of interest with his role as departmental secretary (Read 1990: 290-301). However, Perkins re-emerged in the 1990s as an elected ATSIC Commissioner, so his career in national Indigenous public leadership simply shifted, quite quickly, from the administrative to the (quasi-) political sphere.

Charles Perkins' career illustrates the way in which Australian Indigenous public leaders can move between the administrative, political and societal spheres over time, all the time maintaining their identity-based commitment to Aboriginal interests. Another example of this is John Ah Kit, who became the first Aboriginal minister in the Northern Territory Legislative Assembly in the Martin Labor Government elected in 2001. In the early 1980s, Ah Kit worked for the Commonwealth Department of Social Security assisting Indigenous people in the Katherine region of the Northern Territory to gain access to their recently-won income support entitlements. He then became the manager of an Indigenous community-sector organisation providing accommodation and related services to Aboriginal town campers in Katherine. Ah Kit then moved to Darwin 
to become the Director of the Northern Land Council, a Commonwealth statutory creation which has a high degree of operational autonomy to work in the interests of Aboriginal traditional owners of land, but is still ultimately a part of Commonwealth administration. In the early 1990s, Ah Kit returned to Katherine and the Indigenous community sector as Executive Director of the Jawoyn Association, an organisation working with the Aboriginal land owners of the Katherine region. In this role he helped negotiate one of the first post-Mabo native title agreements with a mining company at Mt Todd in 1993. In 1995, Ah Kit became the member for Arnhem in the Northern Territory Legislative Assembly and so began his career as an elected politician. In retirement since 2005, Ah Kit has also occasionally re-emerged as a public leader. For example, in 2007, he stood beside Pat Turner as a critic of some of the land aspects of the Commonwealth's intervention in the Northern Territory (Turner and Watson 2007).

Both Charles Perkin's and John Ah Kit's stories illustrate the way in which Indigenous leaders can move between the administrative, political and societal spheres in the course of a public leadership career. They also suggest that a conventional administrative career alone might be somewhat too constraining for many Aboriginal public leaders who see their primary task as the promotion of Aboriginal interests. Without ATSIC's elected arm, the options for a political career based on Indigenous votes are also limited to a few parliamentary seats in the Northern Territory and one or two in Western Australia. Beyond this, there is, theoretically, the possibility of building an Indigenous political career on party service and non-Indigenous votes, as some of the current small crop of Indigenous Labor members in the more southern state parliaments would appear to have done. But there is still no easy, or clear, path for Indigenous political careers. So, in many ways the most obvious and most likely path for Indigenous public leadership is through societal leadership, with occasional opportunistic forays into political and administrative spheres.

In many ways this emphasis on the civic sphere among Indigenous leaders is entirely understandable. As 't Hart and Uhr (this volume) note, leaders tend to monitor and challenge the political and administrative spheres, rather than defend or endorse them. This is a very comfortable position for Indigenous leaders, who wish to assert the distinctiveness of their identity and historical perspectives. This is, in many ways, Noel Pearson's point in the Weekend Australian article quoted above: that being on the outside monitoring and challenging politics and administration is the psychologically comfortable position for Indigenous public leaders. In terms of positions occupied, Noel Pearson's own career bears out this point. Over the 15 years since he rose to prominence as the Cape York representative in the 1993 Indigenous team negotiating the passage of the Commonwealth's Native Title legislation, Pearson has, to my knowledge, always remained outside direct public sector employment. He has 
worked for a variety of community-sector or societal bodies, like the Cape York Land Council and the Cape York Institute for Policy and Leadership, which accept government money to undertake certain tasks but which, ultimately, guard their independence and autonomy from governments quite strongly.

Many other Aboriginal leaders also seem most at home in the societal sphere. Pat Dodson, for example, since retiring from being chair of the Commonwealth-appointed Council for Aboriginal Reconciliation in 1997, has worked in a private capacity for the Lingiari Foundation. While brother Mick Dodson, since finishing as HREOC's Aboriginal and Torres Strait Islander Social Justice Commissioner, has become a professor at The Australian National University and, internationally, a member of the United Nations Permanent Forum on Indigenous Issues. Two other prominent Indigenous public leaders in the university sector are professors Marcia Langton at the University of Melbourne and Larissa Behrendt at the University of Technology Sydney.

However, Pearson's criticism of his fellow Aboriginal leaders is not so much about the positions they occupy in the system of public leadership as in the strategies they pursue. Pearson is an advocate of Indigenous leaders pursuing more 'insider' strategies, even though they might do so predominantly from 'outsider' positions of societal leadership within the community sector. To illustrate and develop this idea further I will return to some earlier events.

\section{Insider and outsider strategies of indigenous leadership}

After the 2001 expiry of the Commonwealth-appointed Council for Aboriginal Reconciliation, a new body, Reconciliation Australia, took over the reconciliation cause at a somewhat greater distance from government. In May 2005, Reconciliation Australia organised a National Reconciliation Planning Workshop, in an attempt to re-invigorate the idea of reconciliation between Indigenous and settler Australians in the lead up to the 40th anniversary of the famous 1967 Aborigines constitutional alteration referendum. Reconciliation had, in their view, become somewhat stalled under the Howard government's focus on 'practical' measures in Indigenous affairs and its hesitancy both about endorsing Indigenous rights and about revisiting past wrongs. Prime Minister Howard was invited to speak fairly early in the May 2005 Workshop and there was a strong reaction among his audience when he uttered the following words:

Reconciliation is about rights as well as responsibilities. It is about symbols as well as practical achievement. It is about the past as well as being about the present and the future (Howard 2005)

After the Prime Minister had left the workshop, Noel Pearson reminded others of those words. He encouraged a strategy among those assembled of accepting these words in good faith, repeating them back to the Prime Minister and trying to hold him to them. Others, however, were more sceptical, focusing on some 
of the surrounding words which suggested more continuity in the Howard government's approach to reconciliation. A difference of opinion developed among the Indigenous delegates, in which Pearson occupied something of a minority position. The majority distrusted Howard and were inclined to continue doing so, despite his words.

In retrospect this was, perhaps, just one of many instances in which Pearson was advocating the adoption of an 'insider' strategy - in which the best possible construction is put on what people currently say, or what is currently written in official documents, and then using this to push as hard as possible for people to deliver on that best possible construction of their words. The 'outsider' strategy, by contrast, is to hold onto previous events which suggest less empathy and opportunity and to distrust new, more sympathetic words and actions until they are built on and proven.

Another instance of Pearson advocating an 'insider' strategy can be seen right back at the beginning of his public leadership career in his 1993 Boyer Lecture. Native Title had just been recognised by the Australian High Court as a common law right and the Commonwealth government was in the throws of developing legislation to statutorily recognise and deal with it. Pearson concluded his lecture as follows:

The test of credibility of a strategy is not whether the approach is radical or conservative, but whether it is smart or dumb, and whether it enhances or jeopardises the rights and interests of one's people.

The politics of victims asserts that unless the dominating State accepts us on our own terms, any complicity, any dealing constitutes an unacceptable relinquishment of our power. For a long time, the only political currency which Aboriginal people could use was their refusal to be involved. Now that the non-Aboriginal legal system has offered something in the way of rights, however narrow, to refuse to engage in the game and fail to appreciate the rules and its limitations - even if our purpose be to disrupt the game - no longer seems smart. The challenge is to negotiate the expansion of those rights without losing ground and without surrendering the chances of future advances in a struggle which has incrementally advanced and whose destination is still long in arriving (Pearson 1994: 101).

Again we see Pearson encouraging his fellow Indigenous leaders to engage with and put a positive construction on emerging political circumstances in order to extract the best opportunities from them for Aboriginal interests. And again we see him judging quite harshly his Aboriginal leadership colleagues who find more comfort in 'outsider' stances of principle. 
Among Indigenous societal leaders perhaps one of the most well known takers of 'outsider' stances over the last three decades has been Tasmanian Aboriginal, Michael Mansell, who is a lawyer working for the Tasmanian Aboriginal Centre and a long time Secretary of the self-proclaimed Aboriginal Provisional Government. Mansell has long maintained that Aboriginal people have never recognised the sovereignty of the settler state and, hence, have maintained their own sovereignty. His Provisional Government once produced passports for Aboriginal people and in 1987 he and some colleagues doubly confronted Australian authorities by attempting to use these passports while travelling to and from the then pariah state of Libya. In the 1990s Mansell refused to participate in elections for the Aboriginal and Torres Strait Islander Commission because doing so required Indigenous people to be on the Commonwealth Electoral Roll and hence, as Mansell saw it, to recognise settler sovereignty. Effectively, this also stopped Mansell, and others who followed him, from participating in other elections as well.

In more recent times, Mansell has also explicitly criticised Noel Pearson for his more insider approach to government. In a recent article in a book focused on the Howard government's intervention in Northern Territory Aboriginal communities from mid-2007, Mansell wistfully recalled the more enlightened days of the 1970s and 1980s, before lambasting the Howard government and those who have worked with it. He criticised Pearson both for being 'too close' to the Keating Labor government in the Native Title negotiations of 1993, and of 'courting the conservatives' and 'slamming the left' after Howard came to power in 1996. He suggested that Pearson had 'replaced a national Aboriginal political voice' with his own, and that while most Aboriginal leaders had been 'sacked' or 'went home' after the election of the Howard Government, Pearson had regrouped and courted 'the new, extreme conservatism'. Mansell also argued that there was a 'contradiction' in Pearson's position, in that 'relying on the coercive powers of government' to implement his desired welfare reform agenda, Pearson was denying Aboriginal 'people the right to choose' (Mansell 2007: 79-80).

These are harsh words, to which, Noel Pearson has not, to my knowledge, responded directly. However, Pearson has at times made some more general comments about Aboriginal leadership, which could be seen as indirectly critical of Mansell, and others of his strategic inclinations. In a more substantial article published in 2007, Pearson wrote the following:

In my (relatively) short experience, I have endured my fair share of fanciful separatist rhetoric - and plenty of inane stunts and speeches - founded on vague and insufficiently grasped theories. As long as some key words and concepts are sprinkled amidst the denunciations, then any lunatic can be a leader. I've often had the sense that we are 
playing delusional games in our own little sandpits. We want our sovereignty recognised by the International Court of Justice, and in the meantime I'm off to the TAB and the pub (Pearson 2007b: 20-1).

\section{Exclusive or complementary roles?}

Pearson and Mansell, it seems to me, are each rather harsh in their judgments of those who adopt opposing strategies to their own preferred mode of operation in Australian public life. In many ways their insider and outsider strategies play complementary roles in relation to each other. This was evident back in 1993 in negotiations around Native Title legislation, when Pearson worked more closely with the Labor Government and Mansell with the Senate crossbenches. And it may be similarly the case in more recent times, when Pearson has engaged with a Coalition government over welfare reform while Mansell and other Indigenous leaders have kept other agendas alive more on the margins of public debate, such as the demand for Indigenous-specific rights.

Analytically, we need to recognise that insider and outsider roles and strategies feed off each other in public life, with each reinforcing and complementing the other as much as being directly opposing alternatives. Insider strategies, and strategists, need outsiders also to be present in the public realm in order for their 'insidedness' to be effective while outsiders also rely on insiders to carry at least some part of their principled cause into practice. Perhaps Pearson's complaint about his fellow Indigenous leaders is more one of numbers. He sees more Indigenous leaders pursuing strategies at odds with government than working in partnership with government like himself. And yet, interestingly, among those of whom Pearson has been most critical in recent times are some, like Marion Scrymgour —in 2008 the Deputy Chief Minister in Northern Territory Labor Government - who positionally, are far more insiders than Pearson. Their experience over the last few years, in particular, would seem to be worthy of further study for what it can tell us about the insider and outsider roles and strategies of Indigenous public leaders.

\section{References}

Board of Inquiry into the Protection of Aboriginal Children from Sexual Abuse (BIPACSA), 2007, Ampe Akelyernemane Meke Mekarle: 'Little Children are Sacred', (Rex Wild and Pat Anderson, Inquiry Co-Chairs), Northern Territory Government, Darwin.

Howard, J., 2005, ' Transcript of the Prime Minister The Hon. John Howard MP Address at the National Reconciliation Planning Workshop', Old Parliament House, Canberra, 30 May.

Mansell, M., 2007, 'The Political Vulnerability of the Unrepresented', in J. Altman and M. Hinkson (eds), Coercive Reconciliation: Stabilise, 
Normalise, Exit Aboriginal Australia, Carlton: Arena Publications, pp. 73-84.

Pearson, N., 1994, 'Mabo: Towards Respecting Equality and Difference', in M. Yununipingu, D. West, I. Anderson, J. Bell, G. Lui, H. Corbett and N. Pearson, Voices from the Land: 1993 Boyer Lectures, Sydney: ABC Books, pp. 89-101.

Pearson, N., 2007a, 'Action only way forward', The Weekend Australian, 7-8 July.

Pearson, N., 2007b, 'White guilt, victimhood and the quest for a radical centre', Griffith Review, Edition 16, Brisbane: Griffith University.

Read, P., 1990, Charles Perkins: A Biography, Ringwood Victoria: Viking.

Turner, P. and N. Watson, 2007, 'The Trojan Horse Unrepresented' in J. Altman and M. Hinkson (eds), Coercive Reconciliation: Stabilise, Normalise, Exit Aboriginal Australia, Carlton: Arena Publications, pp. 205-12. 